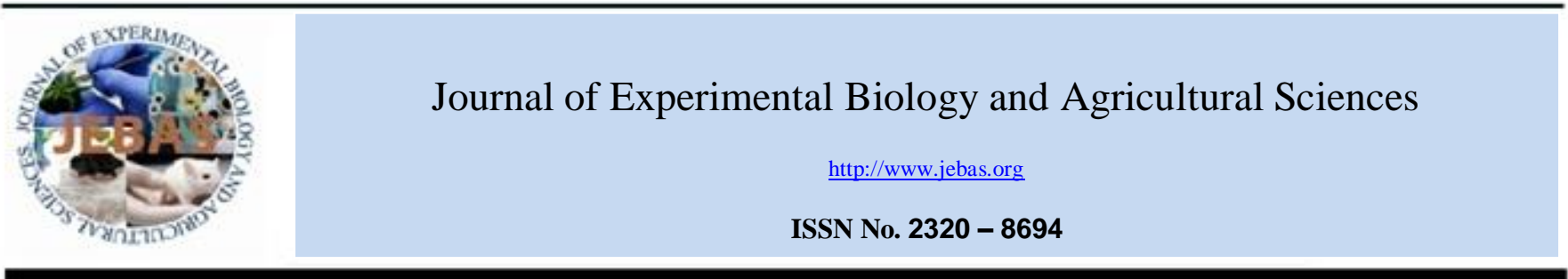

\title{
PRODUCTION OF BIOFUEL FROM SUGARCANE BAGASSE WASTES USING Saccharomyces cerevisiae
}

\section{Wafa A Baz, Lubna S Nawar, Magda M Aly*}

King Abdulaziz University, Faculty of Science, Department of Biology, Jeddah, Saudi Arabia

Received - October 07, 2017; Revision - November 11, 2017; Accepted - December 07, 2017

Available Online - December 27, 2017

DOI: http://dx.doi.org/10.18006/2017.5(6).871.877

KEYWORDS
Biofuel
Bioethanol
Biomass
Saccharomyces cerevisiae
Fermentation

* Corresponding author

E-mail: magdammali@hotmail.com (Magda M Aly)

Peer review under responsibility of Journal of Experimental Biology and Agricultural Sciences.

Production and Hosting by Horizon Publisher India [HPI] (http://www.horizonpublisherindia.in/).

All rights reserved.

\begin{abstract}
The dry pulpy fibrous residue that remains after crush of sugarcane stalks is called Bagasse. It is Agroindustrial solid wastes which accumulated each day, causing big environmental problems. Saccharomyces cerevisiae is a unicellular fungus and has an interesting role in bioethanol production. In this study, two isolates of $S$. cerevisiae were used for bioethanol production from bagasse. In this study, Sugar cane bagasse were collected, hydrolyzed with concentrated $\mathrm{HCl}$ and used as a main carbon source (30 g/l). The growth curves of the two tested strains of $S$. cerevisiae were the same. The effect of temperature and $\mathrm{pH}$ levels on the growth, carbohydrates yields, and mainly bioethanol productivity from sugarcane wastes was studied for both Saccharomyces strains. The best conditions for bioethanol productivity was in fermentation medium after 3 days of growth at $\mathrm{pH} 6$ and $30^{\circ} \mathrm{C}$. In conclusion, Saccharomyces can be used for bioethanol production with the lowest possible costs from environmental wastes.
\end{abstract}

All the article published by Journal of Experimental Biology and Agricultural Sciences is licensed under a Creative Commons Attribution-NonCommercial 4.0 International License Based on a work at www.jebas.org.

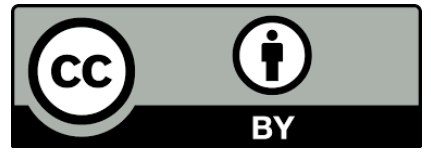




\section{Introduction}

As a result of the rapidly increasing consumption of fossil fuel during the past few decades, problems of growing energy dependency, the risk of the energy supply shortage, and the problem of greenhouse gases emissions in the atmosphere are also increased. Increasing the use of bio-energy and decreasing the dependency on fossil can be a possible solution of these problems (Ajanovic, 2011; Ajanovic, 2013). At present, the world's biofuel production is essentially low, but incessantly rising as a result of the fact that several countries around the world have already set targets to replace a certain percentage of their fossil fuel usage with biofuel. For example, the European Union had a target to replace $5.75 \%$ of the fossil fuel used in the transportation section with biofuel. The second target of the E.U. is to replace $10 \%$ of the fossil energy used for transportation with a renewable energy source by 2020 (EUR, 2016; International Energy Agency, 2016).

Now in these days, the major feedstock used for liquid biofuel production depends on agriculture food crops. For example, corn, wheat, sugar beets, and sugar canes are widely used for bioethanol production. For biodiesel production, oil seeds such as soybean, rapeseed, sunflowers, and palm oil are also being used (Demirbas, 2008a). The availability of these feed stocks differs from one region to another as a result of climatic factors. According to Ajanovic (2013), the major feedstock used to produce bioethanol is wheat, which accounts for $70 \%$, whereas the use of barley for bioethanol production accounts for just $15 \%$, followed by $10 \%$ for corn, and $5 \%$ for rye of the total bioethanol production in the European Union in 2008. Rapeseed is used to produce $79 \%$ of the European Union's biodiesel, where 18\% of the production comes from soybean, and just 3\% is based on sunflowers. Agroindustrial wastes included natural (organic) and non-natural of unwanted materials, produced mainly from agriculture operations (Quintero et al., 2011; Koçar \& Civa, 2013; Sarkar et al., 2012; Qiu et al., 2014; Visioli et al., 2014). Solid Agroindustrial wastes are wastes in solid forms such as grape pomace, sugar beet pomace, potato starch residues, raw corn starch, sugarcane bagasse etc (Rabi et al., 2009; Koçar \& Civa 2013; Visioli et al., 2014). Furthermore, agricultural wastes can be sugar-containing residue such as sugarcane and starchcontaining residues (Koçar \& Civa 2013; Visioli et al., 2014). Additionally, Agroindustrial wastes can be either degradable wastes or non-degradable (Rabi et al., 2009).

Biofuels as a source of alternate can be derived from biomass which include cultivation crops, wood, by-product waste of agricultural crops, animal waste, algae, sewage biosolids and food manufacturers waste (Demirbas, 2008 a, Demirbas 2008b; Demirbas, 2009; Demirbas, 2011). Biomass can be converted by using thermo-chemical or biological methods. Thermo-chemical methods include direct combustion providing electricity, heat and mechanical power. Biological conversion methods include fermentation of the biomass to produce energy carries like hydrogen, ethanol and biogas, or extraction of oils from the biomass for biodiesel production (Costa \& de Morais, 2011). So the main types of biofuels are Bioethanol, Biodiesel, Biohydrogen and biogas (Uçkun Kiran et al., 2014; Demirbas \& Fatih Demirbas, 2011).

Brazil and USA are producing more than $80 \%$ of all biofuels production around the world. Raw materials are varied from country to another. In USA, wood, straw, wheat and mainly corn are the principle materials. Sugarcane is the most used raw materials in Brazil (International Energy Agency, 2016; Koçar \& Civa, 2013; Kumar et al., 2013; Petrova \& Ivanova, 2010).

Sugars can be converted to bioethanol through anaerobic fermentation where one molecule of glucose was converted to 2 molecules of ethanol, 2 molecules of $\mathrm{CO}_{2}$ and 2 molecules of ATP (Kun, 2003). Bioethanol can be produced from fermentation of simple sugar and convert them into ethanol (Demirbas, 2008b; Demirbas, 2009). Simple sugars which are fermented to one of the biofuels products are generally obtained after biomass pretreatment using physical methods such as heat and pressure; chemical methods such as acidic and alkali pre-treatment and enzymatic methods by using specific enzymes (Champagne, 2007; Quintero et al., 2011; Schlosser \& Blahusiak, 2011; Qiu et al., 2014; Visioli et al., 2014; Khawla et al., 2014).

Fermentable sugars derived from pre-treated cellulose, hemicelluloses and starch can also convert in to ethanol (Binod, et al., 2010; Petrova \& Ivanova, 2010; Hahn-Hägerdal \& GorwaGrauslund, 2010). Furthermore, bioethanol production from fermentable sugars can be preceded by either simultaneous saccharification and fermentation (SSF) or separate enzymatic hydrolysis and fermentation (SHF) processes. SSF is more favoured because of its low potential costs and its production can be enhanced by applying thermo-tolerant microorganisms such as Kluyveromyces marxianus, Candida lusitaniae, Zymomonas mobilis or with the help of mixed culture of microorganisms like Brettanomyces clausenii and Saccharomyces cerevisiae (Binod et al., 2010; Petrova \& Ivanova, 2010; Sheikh et al., 2016).

S. cerevisiae, Hanseniaspora uvarum, Starmerella bacillaris and Z. mobilis can ferment glucose to ethanol with higher yields which known as glucose and starchy based ethanol production microorganisms (Rabi et al., 2009; Petrova \& Ivanova, 2010; Sheikh, et al., 2016). Further, Pichia stipitis, Escherichia coli and Klebsiella oxytoca which known as lignocellulosic and mixedsugars based ethanol production microorganisms also help in the production of biofuel (Sheikh et al., 2016). The aim of this study was determination of the best growth conditions for maximum 
biofuel (bioethanol) production by $S$. cervesia (baker's yeast) from local very cheap sugarcane bagasse. The impacts of temperature and $\mathrm{pH}$ levels on sugar production were also evaluated during the study.

\section{Materials and Methods}

\subsection{Sugarcane bagasse collection and acid hydrolysis}

The sugarcane bagasse wastes were collected from local fresh juices shops, Jeddah, Saudi Arabia. The collected sugarcane bagasse was dried at $80^{\circ} \mathrm{C}$ for three days and powder by electrical blender. Acid hydrolysis of sugarcane bagasse was carried out by using $0.5 \%$ Hydrochloric acid which was added to the obtained powder. This was followed by the autoclaving and prepared autoclaved at 1.5 atmospheres pressure and $121^{\circ} \mathrm{C}$ for $15 \mathrm{~min}$. Finally, the samples were cooled and glucose concentration was determined. The clear filtrate was adjusted to approximately reach pH 6.5 and preserved until used.

\subsection{Used microorganism}

Pure culture of $S$ cerevisiae was obtained from the Department of Biology, KAU, Saudi Arabia while the commercial formulation of S. cerevisiae was purchased from Hyper market, Jeddah, Saudi Arabia.

The antibiotic E-MOX $(5 \mu \mathrm{g} / \mathrm{ml})$ was added to the growth medium during purification of the commercial yeast from contamination by bacteria, and incubation was carried out for 24 hours at $25^{\circ} \mathrm{C}$. Stock cultures of both isolates of S. cerevisiae were maintained at $4^{\circ} \mathrm{C}$ on Yeast-Malt (YM) medium which was composed of (g/l): Yeast extract, 3; Malt extract, 3; Peptone, 3; Glucose, 10; Agar, 20; pH 6.5. To maintain good viability for ethanol production, the culture was regenerated after every 3 weeks. The pre-culture was prepared by growing cells obtained from a newly prepared slant of 24 hours old and incubated at $25^{\circ} \mathrm{C}$ in $250 \mathrm{ml}$ Erlenmeyer flasks containing $50 \mathrm{ml}$ of the YM medium. The flasks were incubated with shaking at $180 \mathrm{rpm}$ for 24 hours at $25^{\circ} \mathrm{C}$ in an incubator shaker (Model: JSSI 200T-JSR).

Production medium consisted of $(\mathrm{g} / \mathrm{l})$ : yeast extracts 0.5 , $\mathrm{K}_{2} \mathrm{HPO}_{4}, 1 ; \mathrm{KH}_{2} \mathrm{PO}_{4}, 1.2 ; \mathrm{MgSO}_{4} .7 \mathrm{H}_{2} \mathrm{O}, 0.5 ; \mathrm{NaCl}, 0.5$ at $\mathrm{pH} 7.0$ was prepared. Hydrolysed Sugarcane bagasse solution was the principle solution for the medium and the medium was distributed in $30 \mathrm{ml} \mathrm{screw}$ caps bottles, autoclaved at $121^{\circ} \mathrm{C}$ for $15 \mathrm{~min}$ and inoculated with $3 \mathrm{ml}$ of the preculture $\left(4 \times 10^{5} \mathrm{cfu} / \mathrm{ml}\right)$. All tests were done in triplicates and mean value was calculated.

\subsection{Effect of different $\mathrm{pH}$ levels}

Both commercial and standard S. cerevisiae isolates were grown in the fermentation medium with different $\mathrm{pH}$ values and all bottles were inoculated with $3 \mathrm{ml}$ of inoculums at $25^{\circ} \mathrm{C}$ for 5 days Ethanol content in fermented samples was estimated after 24 hours of incubation and continuous till the end of study.

\subsection{Effect of different temperature}

Growth and bioethanol production was carried out in fermentation medium with $3 \mathrm{ml}$ of pre-culture. This mixture was incubated at different temperatures viz. 25, 30, 37 and $40^{\circ} \mathrm{C}$ for 5 days. Ethanol content in fermented samples was estimated after every 24 hours. .

\subsection{Moisture contained of sugarcane bagasse wastes}

To determine the moisture of sugarcane bagasse waste, samples were weighed and dried at $105^{\circ} \mathrm{C}$ in an oven for 48 hours until the weight of samples become stable.

\subsection{Growth estimation}

Yeast growth was detected by measuring the absorbance at $660 \mathrm{~nm}$ $\left(\mathrm{A}_{660 \mathrm{~nm}}\right)$ using UV-10 Shimadzu spectrophotometer and non inoculated fermentation medium was used as a blank. The relationship between $A_{660 \mathrm{~nm}}$ of the yeast suspension and its dry weight was prepared.

\subsection{Sugar contained of sugarcane bagasse wastes}

The phenol sulphuric acid method was used to estimate the total carbohydrates (Dubois et al., 1956). One $\mathrm{ml}$ of sample solution was mixed with $1 \mathrm{ml}$ of $5 \%$ phenol and the obtained mixture was vortex well. Five $\mathrm{ml}$ of concentrated sulphuric acid were added and the mixture was heated in a water bath for $5 \mathrm{~min}$ and after 30 min. at room temperature, the absorbance was read at $490 \mathrm{~nm}$. Dinitrosalicylic Acid Reagent was used to measure the amount of reducing sugars as described by Miller et al., (1960).

\subsection{Ethanol Determination by Gas Chromatography}

In each sample, ethanol production was estimated after fermentation process using gas chromatography (Agilent Model headspace gas chromatography HS-GC-7890A) according to the method described by Doelle \& Greenfield (1985) The applied conditions were Poropack Q as a column material, nitrogen as carrier gas $(12 \mathrm{ml} / \mathrm{min})$, run time $(4 \mathrm{~min})$, column temperature $260^{\circ} \mathrm{C}$, detector and injection temperatures were $280^{\circ} \mathrm{C}$ and $250^{\circ} \mathrm{C}$, respectively and the yield of ethanol was calculated.

\subsection{Statistical analysis}

Three replicates for each experiment were carried out and the mean value was recorded. Student t- test using SPSS version 16 was applied to detect any significant differences between the 
commercial $S$. cerevisiae and the standard $S$. cerevisiae at $\mathrm{p}<0.05$

\section{Results and Discussion}

Ethanol can produce by $S$. cerevisiae from fermentation of sugarcane bagasse wastes which were used after acidic hydrolysis as a medium for ethanol production. Already few studies were conducted on sugarcane bagasse wastes from local resources, this study also provides information about the fermentation conditions for ethanol production from sugarcane bagasse by two strains of S. cerevisiae.

Sugarcane bagasse wastes were collected from different places, dried and powdered. The sugars were extracted, hydrolyzed used for production of ethanol by commercial and standard $S$. cerevisiae. Moisture and ash content of sugarcane bagasse wastes were determined (Table 1). The mean moisture value was $42 \%$ and ash contained was $4.3 \%$. Generally, S. cerevisiae is widely used for most fermentation processes due to the presence of saccharifying enzymes and the obtained glucose was converted to ethanol and ethanol quantity was obtained from the equation (Meenakshi \& Kumaresan, 2014):

\section{Glucose (1 mole $) \underset{\text { Yeast }}{\longrightarrow}$ Ethanol $(2$ mole $)+$ Carbon dioxide $(2$ mole $)+$ Heat}

Table 1 Moisture content $\%$ and ash $\%$ of sugarcane wastes

\begin{tabular}{|c|c|}
\hline Moisture and Ash content & sugarcane bagasse waste \\
\hline Moisture content ( \%) & $42.0 \pm 2.44$ \\
Ash ( \%) & $4.3 \pm 0.27$ \\
\hline
\end{tabular}

Fermentation yields which is defined as the amount of ethanol produced in relation to the maximum ethanol that could be produced from the initial sugars. By stoichiometric reaction, 1 mole of glucose could produce 2 moles of ethanol, so $100 \mathrm{~g}$ of glucose could produce $46 \mathrm{~g}$ of ethanol if the conversion were $100 \%$. Thus, the yields were determined by the following formulas:

\section{EtOH $\max =$ Initial glucose $\times 46 / 100$}

EtOH max is the maximum production of ethanol obtained from the available glucose (initial glucose concentration), 46 is GayLussac coefficient for glucose.

\section{EtOH yield $(\%)=$ Sample EtOH concentration $\times 46 / \%$ of} EtOH max of theoretical yield

Bioethanol production for both commercial and genetically modified species was maximum after 72 hours, thus all experiments were carried out for 72 hours (Figure 1). The initial $\mathrm{pH}$ is one of the important factors that affect the performance of

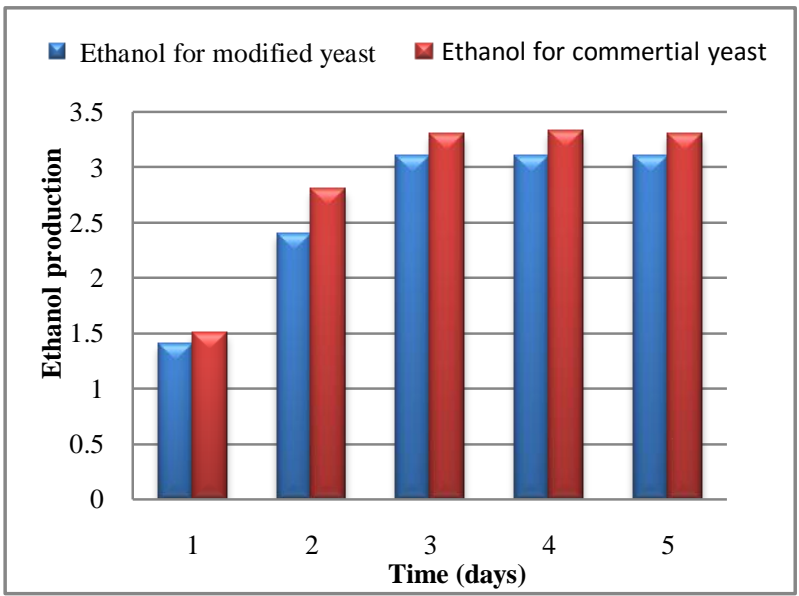

Figure 1 Bioethanol production by commercial and standard $S$. cerevisiae after different incubation period

the microbes. The effect of $\mathrm{pH}$ on ethanol fermentation was studied at different $\mathrm{pH}$ ranging from $\mathrm{pH} 4.0$ to 8.0 for the two used yeast strains namely commercial $S$. cerevisiae and genetically modified $S$. cerevisiae. The initial carbon source concentration was adjusted to $30 \mathrm{~g} / \mathrm{l}$ and the medium was inoculated with $3 \mathrm{ml}$ inoculums, age 24 hours old culture and incubation was carried out at $30^{\circ} \mathrm{C}$, for 72 hours of fermentation period. Glucose conversion was continuing simultaneously during the fermentation. Theoretically, glucose was consumed at the end of fermentation in both strains completely. As shown in Table (2)

Table 2 Effect of different $\mathrm{pH}$ values on sugar content and Ethanol production by two Saccharomyces isolates

\begin{tabular}{|c|c|c|c|c|c|c|}
\hline \multirow[t]{3}{*}{$\begin{array}{c}\text { Initial } \\
\mathrm{pH}\end{array}$} & \multicolumn{3}{|c|}{$\begin{array}{l}\text { Commercial S. cerevisiae } \\
\text { (control) }\end{array}$} & \multicolumn{3}{|c|}{ S. cerevisiae } \\
\hline & \multicolumn{2}{|c|}{ Sugars } & \multirow{2}{*}{$\begin{array}{c}\text { Ethanol } \\
\text { production } \\
(\%)\end{array}$} & \multicolumn{2}{|c|}{ Sugars } & \multirow{2}{*}{$\begin{array}{c}\text { Ethanol } \\
\text { production } \\
(\%)\end{array}$} \\
\hline & Total & Reducing & & Total & Reducing & \\
\hline 4.0 & $35.6 \pm 1.3$ & $31.56 \pm 1.4$ & 0.7 & $35.3 \pm 1.2$ & $32.4 \pm 1.4$ & $0.5^{*}$ \\
\hline 5.0 & $34.8 \pm 1.4$ & $32.0 \pm 1.7$ & 1.9 & $35.1 \pm 1.3$ & $30.0 \pm 1.5$ & $1.8^{*}$ \\
\hline 6.0 & $32.1 \pm 1.7$ & $30.1 \pm 1.0$ & 3.7 & $33.5 \pm 1.4$ & $30.3 \pm 1.5$ & $3.3^{*}$ \\
\hline 7.0 & $33.1 \pm 2.3$ & $31.4 \pm 2.0$ & 2.7 & $33.2 \pm 1.5$ & $30.2 \pm 1.8$ & $2.1^{*}$ \\
\hline 8.0 & $33.7 \pm 1.9$ & $30.3 \pm 2.3$ & 1.9 & $34.2 \pm 1.9$ & $32.8 \pm 1.7$ & $1.5^{*}$ \\
\hline
\end{tabular}

*: significant results at $\mathrm{p}<0.05$ compared to control 
and Figure (2), the ethanol concentration was increased between $\mathrm{pH} 4.0$ to 7.0 and then decreased marginally below this value when the $\mathrm{pH}$ reached 8.0. The maximum ethanol concentration, $3.70 \%$ was obtained for commercial S. cerevisiae and $3.3 \%$ for local strain culture, grown at $\mathrm{pH}$ 6.0. The growth in both cases was increased to about $1.2 \mathrm{~g} / \mathrm{l}$ for commercial strain while it was about $0.9 \mathrm{~g} / \mathrm{l}$ for genetically modified strain. These results are in agreement with that obtained by Turhan et al. (2010) who reported that high ethanol production was obtained by using initial $\mathrm{pH} 5.0$ to 6.0. It was also shown that no ethanol production existed below $\mathrm{pH}$ 4.0. Roukas (1994) reported that maximum ethanol yield, maximum growth rate and biomass concentration were obtained at $\mathrm{pH} 5.5$ on carob as a medium for ethanol production. Similarly, Osman (2011) tested wide initial $\mathrm{pH}$ range and found that at $\mathrm{pH} 3.0$ no growth or ethanol production was observed, while pH 6.0 was the optimum for both biomass and ethanol production. Similar results were obtained by
Mohanty et al. (2009).

Bioethanol production for both commercial and genetically modified $S$. cerevisiae species are highly affected by the temperature variation. Under suggested fermentation protocol, both commercial and genetically modified $S$. cerevisiae strains showed diverse results under different temperature conditions $\left(25^{\circ} \mathrm{C}, 30^{\circ} \mathrm{C}, 37^{\circ} \mathrm{C}, 40^{\circ} \mathrm{C}\right)$ with regarding to bioethanol production (Table 3, Figure 3). Ethanol production was reported $3.7 \%$ for commercial S. cerevisiae and $3.3 \%$ for genetically modified $S$. cerevisiae at $25^{\circ} \mathrm{C}$, while at $30^{\circ} \mathrm{C}$, ethanol productions were 4.15 and $4.01 \%$ for both commercial and genetically modified $S$. cerevisiae, respectively. However, a slight reduction in ethanol production was occurred at $37^{\circ} \mathrm{C}$ for both $S$. cerevisiae strains. The ethanol concentrations were $3.64 \%$ and $3.48 \%$ for both commercial and genetically modified strains, respectively. Consequently, there was no ethanol production was observed at
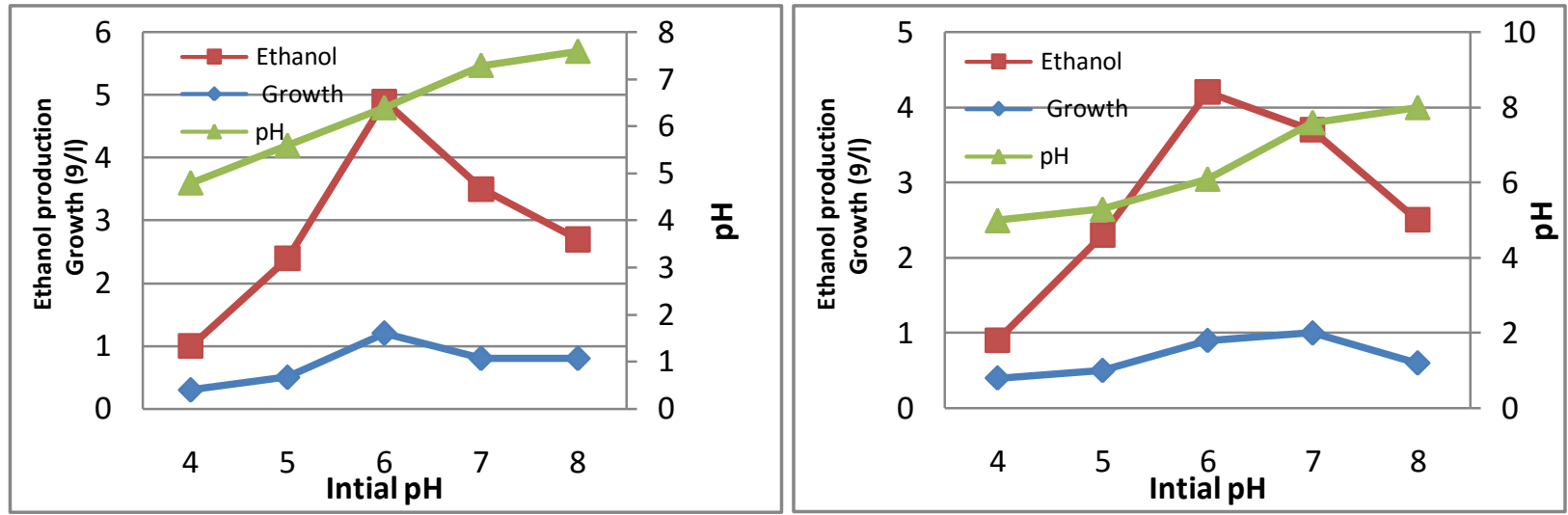

Figure 2 Growth and \% of Ethanol production under different $\mathrm{pH}$ values using Commercial S. cerevisiae (A) and standard S. cerevisiae (B)
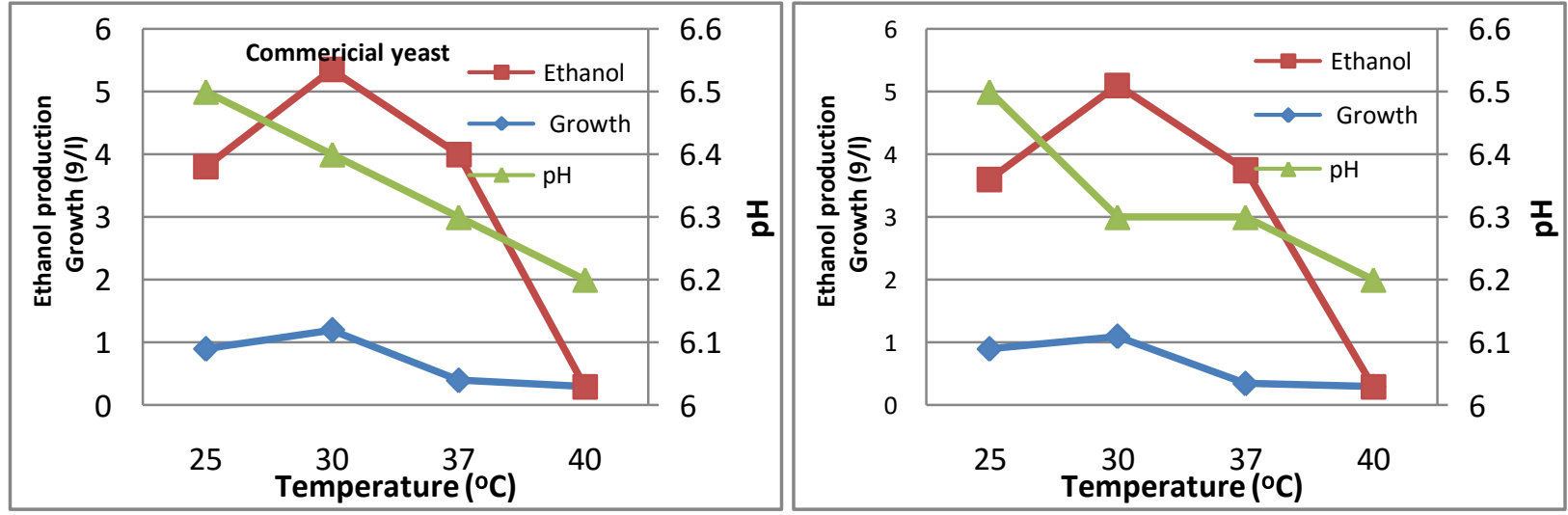

Figure 3 Growth and \% of Ethanol production under different temperature using Commercial S. cerevisiae (A) and standard S. cerevisiae (B)

Journal of Experimental Biology and Agriculture Science http://www.jebas.org 
Table 3 Effect of temperature on sugar content and Ethanol production by two Saccharomyces isolates

\begin{tabular}{|c|c|c|c|c|c|c|}
\hline \multirow[t]{3}{*}{ Temp. $\left({ }^{\circ} \mathrm{C}\right)$} & \multicolumn{3}{|c|}{ Commercial S. cerevisiae (control) } & \multicolumn{3}{|c|}{ S. cerevisia } \\
\hline & \multicolumn{2}{|c|}{ Sugars } & \multirow{2}{*}{$\begin{array}{c}\text { Ethanol production } \\
(\%)\end{array}$} & \multicolumn{2}{|c|}{ Sugars } & \multirow{2}{*}{$\begin{array}{c}\text { Ethanol production } \\
(\%)\end{array}$} \\
\hline & Total & Reducing & & Total & Reducing & \\
\hline 25 & $34.0 \pm 1.4$ & $32.5 \pm 1.7$ & 3.7 & $33.7 \pm 1.4$ & $30.1 \pm 1.0$ & $3.3^{*}$ \\
\hline 30 & $32.2 \pm 1.0$ & $30.2 \pm 1.6$ & 4.15 & $30.8 \pm 1.3$ & $30.1 \pm 1.0$ & 4.01 \\
\hline 37 & $35.5 \pm 1.0$ & $33.5 \pm 3.3$ & 3.68 & $34.1 \pm 1.5$ & $31.3 \pm 1.7$ & 3.45 \\
\hline 40 & $36.5 \pm 2.0$ & $34.4 \pm 2.3$ & 0 & $35.0 \pm 2.3$ & $32.2 \pm 1.7$ & 0 \\
\hline
\end{tabular}

*: significant results at $\mathrm{p}<0.05$ compared to control

$40^{\circ} \mathrm{C}$ for both types of $S$. cerevisiae. These results may be due to the reduction in the growth of $S$. cerevisiae at higher temperature that too decreased the rate of fermentation process.

The data reported here proved that ethanol production for the two tested strains of S. cerevisiae was the highest at $30^{\circ} \mathrm{C}$ and increasing temperature decreased the production of bioethanol. The difference in ethanol production the two tested strains of $S$. cerevisiae at different temperature were not significant. However, ethanol production at $30^{\circ} \mathrm{C}$ showed a massive increase compared to production at $25^{\circ} \mathrm{C}$. These results provide clear evidence that the optimum temperature for growth and ethanol production of both commercial and genetically $\mathrm{S}$. cerevisiae species is $30^{\circ} \mathrm{C}$. This result is against what has been reported by Turhan et al. (2010) but agreed with that obtained by Sheikh et al. (2016).

\section{Conclusion}

In conclusion, the two $S$. cerevisiae strains have the ability to produce bioethanol from very cheap carbon source, Sugarcane bagasse wastes. Results of study recommended that fermentation medium should have $\mathrm{pH} 6$ for maximum ethanol production by $S$. cerevisiae. Further, suitable temperature for bioethanol production was noticed at $30^{\circ} \mathrm{C}$ which gave highest bioethanol production with both commercial and genetically modified $S$. cerevisiae species. There were no significant differences were reported in bioethanol production between the two types of yeasts at different temperature values but the differences were significant at different $\mathrm{pH}$ values. Finally, it can be conclude that commercial and genetically modified $S$. cerevisiae can use sugarcane bagasse wastes for ethanol production and formation process medium and using of $30 \mathrm{~g} / \mathrm{l}$ sugar at $\mathrm{pH} 6$ and $30^{\circ} \mathrm{C}$ for 72 hours yielded the maximum bioethanol production.

\section{Acknowledgments}

The authors acknowledge the help of Dr. Ryan A. Sheikh, Biochemistry Department, Faculty of Science, King Abdulaziz University, Saudi Arabia.

\section{Conflict of Interest}

Authors would hereby like to declare that there is no conflict of interests that could possibly arise.

\section{References}

Ajanovic A (2013) Renewable fuels - A comparative assessment from economic, energetic and ecological point-of-view up to 2050 in EU-countries. Renewable Energy 60:733-8.

Ajanovic A (2011) Biofuels versus food production: Does biofuels production increase food prices? Energy 36:2070-6.

Binod P, Sindhu R, Singhania RR, Vikram S, Devi L, Nagalakshmi S (2010) Bioethanol production from rice straw: An overview. Bioresource Technology 101 : 4767-74.

Champagne P (2007) Feasibility of producing bio-ethanol from waste residues: A Canadian perspective. Feasibility of producing bio-ethanol from waste residues in Canada. Resources, Conservation and Recycling $50: 211-30$.

Costa JAV, de Morais MG (2011) The role of biochemical engineering in the production of biofuels from microalgae. Bioresource Technology $102: 2-9$.

Demirbas A (2009) Political, economic and environmental impacts of biofuels: A review. Applid Energy 86: 108-117.

Demirbas A (2008a) Biofuels sources, biofuel policy, biofuel economy and global biofuel projections. Energy Conversion and Management 49 : 2106-2116. 
Demirbas A (2008b) Importance of biomass energy sources for Turkey. Energy Policy $36: 834-42$.

Demirbas A (2011) Waste management, waste resource facilities and waste conversion processes. Energy Conversion and Management 52:1280-1287.

Demirbas A, Fatih Demirbas M (2011) Importance of algae oil as a source of biodiesel. Energy Conversion and Management 52 :163-70.

Doelle H, Greenfield PF (1985) The production of ethanol from sucrose using Zymomonas mobilis. Appllied Microbiology and Biotechnology. 22:405-410.

Dubois M, Gilles KA, Hamilton JK, Rebers PA, Smith F (1956) Colorimetric method for determination of sugars and related substances. Analytical Chemistry 28: 350-356.

EUR 22066 (2016) Biofuels in the European Union - A vision for 2030 and beyond. European Communities, Luxembourg. Retrieved January 20- 2016

Hahn-Hägerdal B, Gorwa-Grauslund F (2010) Yeast optimization for fermenting C5 and C6 sugars. Journal of Biotechnology 150:10-10.

International Energy Agency (2016) Oil market report. Retrieved February 15/ 2016.

Khawla BJ, Sameh M, Imen G, Donyes F, Dhouha G, Raoudha EG (2014) Potato peel as feedstock for bioethanol production: A comparison of acidic and enzymatic hydrolysis. Industerial Crops Prodroduction 52:144 - 149 .

Koçar G, Civa N (2013) An overview of biofuels from energy crops: Current status and future prospects. Renewable \& Sustainable Energy Reviews 28: 900- 916.

Kumar S, Shrestha P, Abdul Salam P (2013) A review of biofuel policies in the major biofuel producing countries of ASEAN: Production, targets, policy drivers and impacts. Renewable \& Sustainable Energy Reviews 26:822-836.

Kun LY (2003) Microbial biotechnology: principles and application. Singapore: World Scientific Publishing Co. Pte. Ltd.

Meenakshi A, Kumaresan R (2014) Ethanol production from corn, potato peel waste and its process development. Journal Chemical Technological Research 6: 2843-2853.

Miller GL, Blum R, Glennon WE, Burton AL (1960) Measurement of carboxymethylcellulase activity. Analytical Biochemistry 2:127-32.
Mohanty SK, Behera S, Swain MR, Ray RC (2009) Bioethanol production from mahula (Madhuca latifolia L.) flowers by solidstate fermentation. Applid Energy $86: 640-644$.

Osman MH, Shah AA, Walsh FC (2011) Recent progress and continuing challenges in bio-fuel cells. Part I: Enzymatic cells. Biosensors and Bioelectronics 26 : 3087-3102.

Petrova P, Ivanova V (2010) Perspectives for the Production of Bioethanol from Lignocellulosic Materials. Biotechnology and Biotechnology Equipment 24:529-46.

Qiu H, Sun L, Xu X, Cai Y, Bai J (2014) Potentials of crop residues for commercial energy production in China: A geographic and economic analysis. Biomass and Bioenergy 64:110-23.

Quintero JA, Rincón LE, Cardona CA (2011) Production of bioethanol from agroindustrial residues as feedstocks. Biofuels 251- 85 .

Rabi JA, Santos SF, Tonoli GHD, Savastano Jr H (2009) Agricultural wastes as building materials: properties, performance and applications. Agriculture Issues and Policies Series Pp. 219.

Roukas T (1994) Kinetics of ethanol production from carob pods extract by immobilized Saccharomyces cerevisiae cells. Applied Biochemistry and Biotechnology 44 : 49-64.

Sarkar N, Ghosh SK, Bannerjee S, Aikat K (2012) Bioethanol production from agricultural wastes: An overview. Renewable Energy 37:19-27.

Schlosser S, Blahusiak M (2011) Biorefinery for production of chemicals, energy and fuels. Elektroenergetika 4(2):8-15.

Sheikh RA, Al-Bar OA, Soliman YMA (2016) Biochemical studies on the production of biofuel (bioethanol) from potato peels wastes by Saccharomyces cerevisiae: effects of fermentation periods and nitrogen source concentration. Biotechnology and Biotechnology Equipment $30: 497-505$.

Turhan I, Bialka KL, Demirci A, Karhan M (2010) Ethanol production from carob extract by using Saccharomyces cerevisiae. Bioresource Technology 101 : 5290- 5296.

Uçkun Kiran E, Trzcinski AP, Ng WJ, Liu Y (2014) Bioconversion of food waste to energy: A review. Fuel 134:389 399.

Visioli LJ, Stringhini FM, Salbego PRS, Chielle DP, Ribeiro GV, Gasparotto JM (2014) Use of Agroindustrial Residues for Bioethanol Production. Bioenergy Research: Advances and Applications 49-56. 